\title{
Community Involvement in Preparation of EIA Documents as Implementation of Participatory Principles In Law No.32 Year 2009 About Protection and Environmental Management (Study at PT Mandiri Mining Corporindo)
}

\author{
Rahmat, Rahmat \\ Faculty of Law, Universitas Tomakaka \\ email: rahmatlawyers@gmail.com
}

\begin{abstract}
PT. Mandiri Mining Corporindo (MMC) is a mining company of Mangan in Bonehau Village, Bonehau District of Mamuju Regency, West Sulawesi Province with exploration license number 418/2009 and production operation license number 333 of 2010, where production process has started since October 2010, while the area of mining business license owned by PT.MMC is 178 ha covering 178 ha area covering production forest area 125 ha and community plantation 53 ha, but a newly managed area about 30 percent. Since the beginning of the opening of mining companies in this village has raised concerns about the negative impact of environmental damage, given the location of the mine directly bound to the plantation and rice fields of local communities. This is an interesting issue studied from the legal aspects of licensing, especially environmental permissions so that the problems in this research are; First what is the position of Environmental Impact Assesment EIA in PT.MMC environmental permit? Second, how does the community engage in the document of Environmental Impact Assesment EIA PT.MMC implementation. the results of this study indicate that the EIA position in the environmental permit is an absolute obligation and prerequisite if a company violates the environmental permit, the business license or activity may be canceled. And the PT.MMC EIA issuance procedure has been in accordance with the legislation but in its implementation is not in accordance with the planning.
\end{abstract}

Keywords: environmental impact assesment EIA of PT.MMC; environmental permit; licensing law; $A M D A L$

\section{INTRODUCTION}

EIA is a very important part of a plan for environmental or natural resource exploration activities. The legal basis of EIA is contained in Law Number 23 Year 1997 regarding Environmental Management, as it has been amended through Law Number 32 Year 2009 on Environmental Protection and Management hereinafter its implementation rule through Government Regulation No. 27/1999 on environmental impact analysis life and Regulation of the State Minister of Environment No.11 of 2006 on the type of business plan and or activity that must be completed EIA. Thus EIA is a technical means used to estimate the negative and positive impacts that will be generated by a planned activity on the environment, considering that in the preparation of EIA documents it is necessary to 
involve the public widely and openly, ${ }^{1}$ as it is the principle of participative in Law Number 32 of 2009 on the Protection and Management of the Environment. With the implementation of a participatory EIA, then decision-making on the plan of an activity has been based on consideration of ecological aspects. From the above description, then the problem we face is how malaksanakan development that does not damage the environment and natural resources, so that development can improve the environmental capability in supporting the continuation of development as a whole. With the support of environmental capabilities that are maintained and built in harmony and balance, the implementation of development, and the results of development can be implemented and enjoyed on an ongoing basis from generation to generation.

The mining business is one of human effort to improve the quality of its economy, because the mining industry promises prosperity and prosperity of the people. But behind it there is also a big threat to the environment if the mining business management is done irresponsibly. Mamuju District, West Sulawesi Province is an area rich in natural resources potential in the form of gold, oil, natural gas, coal and manganese materials. One of the areas with potential coal and manganese mines, is Bonehau Village, Bonehau District, Mamuju District with an area of 96,176 Km2, which can even be assumed that it could damage the tourism potential in other Regions due to the lack of attention to environmental sustainability that may affect the visit or the decision of the tourists who participate in providing foreign exchange for regional development. ${ }^{2}$

Among the companies that have a mining business license are PT. Mandiri Mining Corporindo (MMC) with exploration license No. 418/2009 and production operation license No. 333 of 2010, which is engaged in mining of manganese, where the production process has started since October 2010. The area of Mining Business License owned by PT.MMC is 178 ha covering a production forest area of 125 ha and community plantation of 53 ha. but the newly managed area is about 30 percent.

Since the beginning of the opening of mining companies in the village of Bonehau has caused pros and cons in the community, where some people judge if the socialization is not done by the company or local government, so it is feared the opening of manganese mining company will cause the impact of environmental damage in various sectors, directly adjacent to the plantations and rice fields of local communities, as Hasmin, a local youth figure (author interview on 19 March 2012). It is, therefore, necessary to have a comprehensive assessment of the environmental law instruments, existing licensing laws and their impact on the communities affected by the development of manganese mining

\footnotetext{
${ }^{1}$ Baharuddin, H. 2008. Hak Gugat Lembaga Swadaya Masyarakat (LSM) Dalam Rangka Kontrol Terhadap Pelayanan Publik, PT. Umitoha Ukhuwah Grafika: Makassar.

2 Bahari, A. F., \& Ashoer, M. (2018. Pengaruh Budaya, Sosial, Pribadi Dan Psikologis Terhadap Keputusan Pembelian Konsumen Ekowisata. Jurnal Minds: Manajemen Ide dan Inspirasi, 5(1), 68-78.
} 
business through an EIA study. This study will examine EIA as an important instrument in every environmental permit, and how it is implemented in PT.MMC that manages manganese mines in Bonehau Village, Mamuju District, West Sulawesi Province. For that matter, this study formulates the following issues: How is the implementation of PT. MMC preparation EIA? And how is community involvement in the EIA document team of PT. MMC ?

\section{METHOD}

This article uses legal research with an empirical approach and forms the formulation of the problem set out to review and provide an analysis of the implementation of EIA pertamabangan business (Study at PT. Mandiri Mining Corporindo in Mamuju District, West Sulawesi Province).

\section{ANALYSIS AND DISCUSSION}

\section{Implementation of PT.MMC EIA Preparation}

Against the implementation of EIA PT.MMC, a survey of thirty respondents comprising communities around the PT.MMC mining site, measured by participation and community involvement in the implementation of the EIA.

The results of the interviews and questionnaires to measure community knowledge on EIA are arranged in the form of tables as follows:

Table.1 Public Knowledge of EIA

\begin{tabular}{llcc}
\hline No & \multicolumn{1}{c}{ Opinions Responden } & Frequency & Percentage \\
\hline 1. & do not know & 20 & 70 \\
2. & know some & 3 & 5 \\
3. & ever heard & 7 & 25 \\
\hline & Total & 30 & 100 \\
\hline
\end{tabular}

Source: primary data, 2016

In the table above there is 70 percent of people do not understand about the EIA and only 30 percent who know some and have heard about the EIA. Furthermore, the researchers conducted a survey of community involvement in the socialization of EIA PT.MMC, found the following things, as much as 10 percent of respondents answered that community involvement only in the early stages of socialization and discussion EIA course, the remaining 90 percent said no even not know about the existence socialization EIA PT.MMC, more fully illustrated in the following table. 
Table 2. Community Involvement in EIA Socialization

\begin{tabular}{clcc}
\hline No & \multicolumn{1}{c}{ Opinions Responden } & Frequency & Percentage \\
\hline 1. & There is socialization at the stage & \\
of announcement and discussion of & 5 & 10 \\
& $\begin{array}{l}\text { EIA } \\
\text { 2. There is no }\end{array}$ & 20 & 80 \\
3. do not know & 5 & 10 \\
\hline & Total & 30 & 100
\end{tabular}

Source: primary data, 2016

From the data presented above, it is clear that in the implementation of the preparation of EIA PT.MMC has not maximally involved the community so that the participative principles explicitly stipulated in Article 26 paragraph (1) to paragraph (3) of Law No.32 of 2009, protection and management of the environment, in the article it is explained that the EIA document is prepared with the involvement of the community in a transparent manner, especially the people who will be affected by a business activity. The question that arises then is whether or not the public involvement in the preparation of the EIA document, the PT.MMC mining business license can be reviewed?

Administrative law enforcement instruments are part of the rule of law (besturen), then the enforcement of state administration law is subject to general principles (government law), namely the principle of validity (rechtmatigheid van bestuur), the principle of efficiency and effectiveness (doelmatigheid an doeltreffendheid), the principle of openness openbaarheid van bestuur) and the principle of planmatigheid (planmatigheid) ${ }^{3}$

Mas Achmad Santosa stated that the administrative law enforcement devices in a legal system and the government should at least include five devices which are prerequisites for the effectiveness of administrative law enforcement in the environmental field ${ }^{4}$. The five devices are :

1. Permission, which is utilized as a control and control device

2. Conditions of consent with reference to EIA, environmental quality standards, legislation

3. Structuring control mechanism;

4. The presence of adequate supervisory officials in both quantity and quality

5. Adminisrative sanctions

${ }^{3}$ Aditia Syaprillah, 2016, Penegakan Hukum Administrasi Lingkungan Melalui Instrumen Pengawasan, Jurnal Bina Hukum Lingkungan, p. 103, vol.I No.1 Oktober 2016.

${ }^{4} \mathrm{lbid}, \mathrm{hal}, 104$ 
There is a model of law enforcement of the administrative environment with some kind of administrative sanctions that are usually applied to violations committed by the perpetrators of activities are:

1. Bestuursdwang (government coercion).

2. Withdrawal of favorable decisions (permits, subsidies, payments, and so on)

3. The imposition of forced money by the government (dwangsom).

4. Imposition of administrative fine (administrative boete). ${ }^{5}$

This view is a form of administrative law enforcement developed in the Netherlands, which is expected to be a comparator in the formation and practice of administrative law in Indonesia.

A pyramid form in enacting sanctions in the enforcement of environmental law is the imposition of administrative sanctions as mentioned above applied systematically and gradually (ranging from mild, medium to heavy), UUPLH set the implementation of three types of administrative sanctions namely:

1. Coercion of government article 25 paragraph (1)

2. Payment of a certain Total of money article 25 paragraph (5)

3. Revocation of business license article 27 paragraph (1) ${ }^{6}$

That enforcement of environmental law in the environmental field has several strategic benefits compared to other law enforcement devices (civil and criminal) such benefits are as follows:

1. Enforcement of environmental administration law can be optimized as a preventive tool

2. Enforcement of administrative law (which is prevention) can be more efficient in terms of financing than criminal and civil law enforcement. Financing for administrative law enforcement includes routine field inspection costs and cheaper laboratory testing compared to evidence collection efforts, field investigations, hiring expert witnesses to prove causality (causality) in criminal and civil cases.

3. The enforcement of the administrative law has more ability to invite community participation. ${ }^{7}$

Administrative law enforcement devices in a legal and administrative system should at least include permits, permit requirements with reference to EIA, environmental

${ }^{5}$ Rahmat, 2015, Hukum Perlindungan dan Pengelolaan Lingkungan Hidup, The Phinisi Press, Yogyakarta, hal 33.

${ }^{6}$ Helmi, 2012. Hukum Perizinan Lingkungan Hidup, Sinar Grafika, Jakarta. hal-27

${ }^{7}$ Loc.cit, hal 35 
quality standards, statutory regulations, regulatory oversight mechanisms, the presence of regulatory authorities and administrative sanctions. ${ }^{8}$ These five devices are the preliminary requirements of the effectiveness of environmental administration enforcement.

Officials authorized to impose administrative sanctions of governmental coercion and payment of a certain Total of money are the Governor. The Governor may transfer the authority to the Regent / Mayor. For the application of administrative sanction in the form of revocation of business license, the authorized person is the officer issuing the business license concerned. The Governor is only authorized to propose the revocation of a business license to the authorized official issuing the permit. Therefore, based on the above studies, the Mamuju District Government of West Sulawesi Province can perform administrative actions in the form of a recommendation to improve the EIA document of PT. Mandiri Mining Corporindo (MMC).

\section{Community Involvement in Assessment Team of PT.MMC EIA Document}

The EIA document assessment shall be undertaken by the EIA Appraisal Commission to assess the EIA documents of strategic business and/or activities, located over one province, located in the disputed territory, in the ocean spaces, and/or their location across the borders of the Republic of Indonesia with other countries. In the implementation of regional autonomy, for the provincial level, the EIA document assessment is undertaken by Provincial Development Planning Agency at Sub-National Level (BAPPEDA), which is to assess businesses and/or activities that are located in excess of one district. For regency/municipality level is also available the assessment team is the officials who have received the certificate of Appraiser (EIA). The EIA document assessment is undertaken for several documents and includes assessments of administrative completeness and document contents.

As for the documents assessed, include :

1. Assessment of the Terms of Reference document.

2. Assessment of Environmental Impact Analysis documents.

3. Assessment of Environmental Management Plan.

4. Assessment of Environmental Monitoring Plan.

The Based on the results of research related to the implementation of PT. MMC AMDAL/EIA issuance as the holder of a business license for manganese mine management in Bonehau Village, Bonehau Subdistrict, Mamuju District, West Sulawesi Province. Based on the author's interview with the head of Bappedalda of Mamuju district as the institution issuing the environmental permit, according to him PT.MMC has fulfilled

${ }^{8}$ Gatra, Dwi, et al. "Stagnancy of Land Use Arrangement Former Cultivation Rights." Substantive Justice International Journal of Law 1.1 (2018): pp. 1-8. 
all the administrative requirements for the issuance of its environmental permit, but in the implementation acting as the assessment team are the officials led by the head of Bappeda (Development Planning Agency at Sub-National Level) formed by the Bupati without involving the affected communities. In Government Regulation No. 27/1999 on an analysis of the environmental impacts, it is explained that the AMDAL/EIA assessment team's membership consists of government elements, affected community representatives, universities/experts, and non-governmental organizations.

There is a kind of ambiguity in EIA policies in which the document is placed as a scientific environmental feasibility study that serves as a tool for decision-making in development. However, the assessment commission charged with assessing EIA consists of the majority of representatives of government agencies that reflect heavy bureaucracy and advocacy representatives. From the composition there may result in the following: (1) environmental feasibility decisions are dominated by votes based on bureaucratic interests; (2) community and NGO representatives as counterbalance forces can easily be captured or co-opted due to various factors; (3) the decision is quite difficult to achieve because the dominant is not an objective scientific consideration but the interests of government or interests of society / NGO unilaterally.

The EIA assessment process should be an important instrument in the management of Natural Resources and Environment, adhering to the principle of prudence in order to maintain the sutainable potential of natural resources that are limited in nature such as mining commodities, especially if the Natural Resources is a buffer for community life, because the community itself is a resource for regional development, as well as to PT.MMC as the initiator or proponent of the EIA should voluntarily have the awareness to abide by implementing environmental management plans in accordance with the principles set forth in Law No.32 of 2009 Environmental Protection and Management is the principle of sustainability.

\section{CONCLUSION}

Based on the description of the discussion that has been raised, the conclusions that can be drawn on the two formulations of the problem are as follows: Implementation procedures for the preparation of EIA PT. Mandiri Mining Corporindo (MMC), does not involve communities that will be affected by mining operations, so it is not in line with the participative principles as referred to in Law no. 32 of 2009 on the Protection and Management of the Environment. Similarly to the evaluation and assessment of EIA documents of PT. Mandiri Mining Corporindo, the elements involved in the EIA assessment team/commission which are still dominated by the bureaucratic elements are not in line with the participative principles. A regulation that reinforces licensing supervision is more 
selective for every business activity that manages Natural Resources as a concrete form of environmental protection and management. In strengthening the regulation as the first suggestion above, one of the important material, content, and substance are regulated is the review and even cancellation of a business license if the procedure of preparing the Company's EIA proved not to involve the affected community.

\section{REFERENCE}

Aditia Syaprillah, (2016), Penegakan Hukum Administrasi Lingkungan Melalui Instrumen Pengawasan, Jurnal Bina Hukum Lingkungan, p. 103, vol.I No.1 Oktober 2016.

Andi Hamzah, (2005). Penegakan Hukum Lingkungan, Sinar Grafika, Jakarta.

Bahari, A. F., \& Ashoer, M. (2018). Pengaruh Budaya, Sosial, Pribadi Dan Psikologis Terhadap Keputusan Pembelian Konsumen Ekowisata. Jurnal Minds: Manajemen Ide dan Inspirasi, 5(1), 68-78.

Baharuddin, H. (2008). Hak Gugat Lembaga Swadaya Masyarakat (LSM) Dalam Rangka Kontrol Terhadap Pelayanan Publik, PT. Umitoha Ukhuwah Grafika: Makassar.

Gatra, Dwi, et al., (2018), "Stagnancy of Land Use Arrangement Former Cultivation Rights." Substantive Justice International Journal of Law 1.1.

H.J.Mukono, (2015), Kedudukan AMDAL Dalam Pembangunan yang berwawasan lingkungan yang berkelanjutan (Sutainable Development), Jurnal Kesehatan Lingkungan Vol.2 No.1.

Rahmat, (2015). Hukum Perlindungan dan Pengelolaan Lingkungan Hidup, The Phinisi Press, Yogyakarta

Undang-Undang Dasar Negara Republik Indonesia Tahun 1945

Undang-Undang No.23 Tahun 1997 tentang Pengelolaan Lingkungan Hidup

Undang-Undang No.32 Tahun 2009 Tentang Perlindungan dan Pengelolaan Lingkungan Hidup 